\title{
Reports
}

\section{An Interview with Joseph Greenberg ${ }^{1}$}

\section{PAUL NEWMAN}

Bloomington, Ind., U.S.A. 22 IV 9 I

Introduction [PN]: Joseph $\mathrm{H}$. Greenberg was born in Brooklyn, New York, on May 28, I9I5. He took his bachelor's degree at Columbia University in 1936 and his Ph.D. at Northwestern University in 1940. After some I4 years' teaching at Columbia, he moved in 1962 to Stanford University, where he has been professor of linguistics and anthropology ever since. Greenberg has been an extremely prolific scholar and has published groundbreaking works in the areas of language classification, typology, and universals, among others. Two volumes of his collected papers (Greenberg 1971 $a$, 1990) have been issued, the latter containing a full list of his writings, and two Festschriften have been published in his honor (Juilland I977, Croft, Denning, and Kemmer 1990). His own thoughts about his career as a linguistic anthropologist are found in Greenberg (1986). The following interview was conducted in July 1989 with a brief continuation in February I99I.

PN: At a point in your academic life when other people might be sitting around collecting honors, you find yourself embroiled in a huge controversy regarding your American Indian classification. ${ }^{2}$ I was wondering how you feel about this situation.

JHG: Well, I didn't start out to be polemical. Maybe in my earlier life, when I was younger, I might have been, but even then I don't think I ever made any ad hominem attacks on anyone. And what's more, the basic outlines of the classification have been known since the early I960s, when I wrote about it [Greenberg 1960]. What I do feel is that there are two distinct things at stake. One

I. (c) I99I by The Wenner-Gren Foundation for Anthropological Research. All rights reserved o0I I-3204/91/3204-0003\$1.00. Initial work on this interview was begun while PN was a fellow at the Center for Advanced Study in the Behavioral Sciences, Stanford, with the support of NSF grant no. BNS 87-00864. The assistance of Keith Denning in preparing the final version is gratefully acknowledged.

2. Greenberg's radical proposal is that there are only three linguistic stocks comprising all of the languages in the Americas: Eskimo-Aleut, Na-Dene, and Amerind, the latter a huge, widespread family.

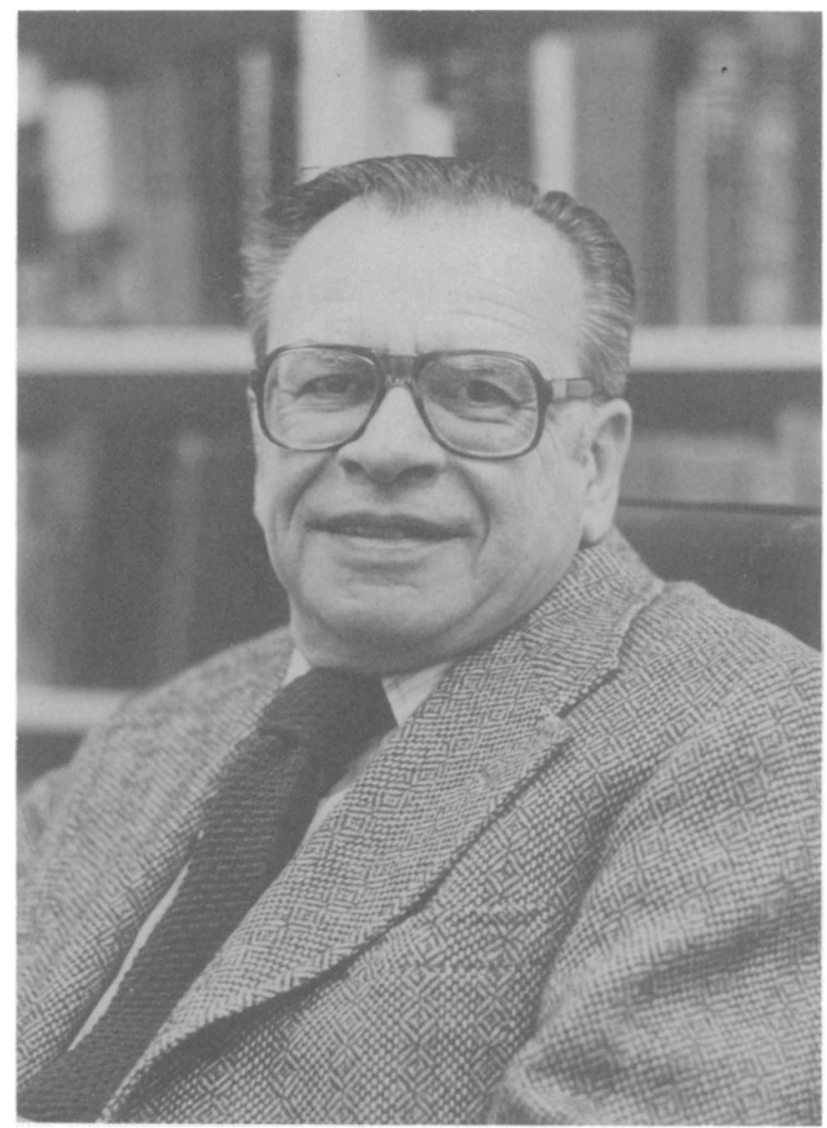

Joseph Greenberg. (Photo News and Publications Service, Stanford University.)

has to do with methodology, and there I am absolutely sure that the American Indianists have been carrying out a method which, if it were applied to Indo-European languages or any acknowledged family, would obviously dismantle it. That is, they are setting up requirements which have nothing to do with what we know about actual processes of language change. I think I showed that pretty clearly in chapter 6 of Language in the Americas [Greenberg 1987], where I demonstrated that in spite of even the most irrelevant criteria, and allowing for them, one still had far more etymologies within Na-Dene than would occur between three branches of Indo-European if one used the same method. Also, I'm quite clear-this is hypothetical, of course, but I'm quite certain-that if something like Indo-European had been spoken in native California, so that, let's say, Slavic corresponded to Maidu, Germanic to Wintun, and so on, 
and then somebody like Sapir ${ }^{3}$ had come along and said that they formed one group, they would have spent a lifetime trying to prove he was wrong. So I'm quite sure that the methodology is right.

The second question is whether I applied my own method correctly. It's possible that I could use this method and make mistakes. Now, let's take the African classification [Greenberg I963a]. It's clear that when dealing with thousands of languages, the only way that you can classify them is to look at them, so somebody has to make the effort. The important thing is not to fight about methodology but actually to apply it. By now, there is a large literature in print about mass comparison-what I've called more recently "multilateral comparison"-but of all of the people who talk about it, no one, with the exception, I believe, of me, has ever tried it. They simply don't want to face the fact that, as I showed in my book, if one just takes presentday Indo-European languages, taking into account a large number of languages at the same time, one immediately sees grouping of the kind that I have suggested. Yet they are unwilling to do that. That is absurd. Instead, they go about with isolated hypotheses of resemblance and then try to prove that two languages or two groups of languages are related. Out of that we'll never get a classification.

PN: The initial response to your classification by specialists in American Indian linguistics was extremely negative [see, e.g., the review by Campbell I988]. Do you think that there has been any change of direction in your favor, especially since the Boulder meeting? ${ }^{4}$

JHG: I think that I'm definitely gaining support, but the support has nothing to do with the linguistic merits of the case; rather, it has come from outside of linguistics. There's been a lot written about the controversy recently, most of it by popular science writers. Now, if these science writers have a background in any field, it's likely to be in biology or anthropology or some such, so that what strikes them is that there is more and more support for my classification from studies of dentition, mitochondrial DNA, population genetics, and so on. Thus one finds that it is this external support which has turned the tide in the same way that at the beginning external things had much to do with acceptance of the African classification. All in all, I think that these external factors have had a greater impact than the arguments about linguistic methodology.

PN: Even so, I suspect that it is hard for your linguistic opponents to be confident that they're right when so much nonlinguistic evidence points in the direction you've established.

3. Edward Sapir (1 884-1939). Throughout his work, Greenberg has always been in the Sapirian tradition. This was particularly the case with his American Indian classification, for which Sapir (I 929) was a direct precursor.

4. "Language and Prehistory in the Americas: A Conference on the Greenberg Classification," Boulder, Colo., March 22-25, I990, organized by Allen R. Taylor.
JHG: Also, my detractors among the American Indianists don't agree with each other. If you look at Campbell and Mithun's book [1979], you see first of all that the people who wrote the different chapters don't all share the view expressed in Campbell and Mithun's introduction, which consists in what they consider a safe thing and ends up with a lot of hedging about whether particular groups like Haida may or may not show a distant relationship. (Here I am reminded of a footnote to an article by [Edgar] Sturtevant involving a controversy with [Franklin] Edgerton about Sievers's law-this had to do with the distribution of /iy/ and /uw/ based on Edgerton's study of Sanskrit-to the effect that just because your opponents disagree with each other doesn't prove that you are right.) But the fact is that some people, such as Campbell and Kaufman (but not Ives Goddard, unless I'm mistaken), appeal to something they call pan-Americanisms in rejecting my Amerind family. Now, once they do that, they have almost given up their case. They say vaguely that someday we'll be able to account for these pan-Americanisms; but obviously, if they exist, they should be very important for American Indian specialists, and they should have a reasonable explanation. Furthermore, in a recent paper on Amazonian languages, Kaufman [1990] has admitted that these do not occur in Eskimo-Aleut and Na-Dene, which clearly points to them as diagnostic characteristics of the Amerind family. For me, the only question that remains-and this is not a trivial one-is that of subgrouping within Amerind.

A lot of the arguments at Boulder showed me that a meeting isn't necessarily the best place to get enlightenment about a question, because when people talk and argue, and so on, facts are often obscured. Take, for example, the question of the pronouns. It must have seemed to some of the people at the meeting who didn't know the languages that this thing was simply a statistical statement to the effect that nasals are more frequent in the New World than in the Old, but it isn't that way at all. I have five full pages in my book enumerating languages from Tierra del Fuego to British Columbia which have either $/ \mathrm{n} /$ in the Ist person or $/ \mathrm{m} /$ in the $2 \mathrm{~d}$ person or both. Such facts are not found anywhere else in the world.

PN: I thought that it was an interesting meeting in that it provided linguists and nonlinguists concerned with New World prehistory an opportunity to interact. The danger, of course, is that some people might not have had the background and training to follow the linguistic arguments.

JHG: As I said, things may sometimes get more obscured than cleared up. For example, take the question of what is meant by the comparative method. It's treated by people as if it were self-evident, but in fact it's a very complicated thing. The way I've tended to treat it is historically, that is, to look at Indo-European and see what Indo-Europeanists really did and what were the things that really counted. The question is, having discovered that Indo-European was a family, how did they decide, 
when they encountered a new language, whether it was Indo-European or not? You find that it had nothing to do with sound correspondences; rather, their approach was to look at things closely and decide what was diagnostic. Hittite, for example, forced them to change the reconstructions. If they had acted according to the preachings of some of the American Indianists, they would have decided that Hittite was all an illusion. In my Boulder paper I cited a passage from Hrozný [1917], whose work led to the acceptance of Hittite as being Indo-European. He doesn't say anything about sound correspondences or things like that; rather, he says, "Take a look at words such as watar 'water', not to mention the genitive wetenas, which shows that you have $\mathbf{r} / \mathbf{n}$ stems, an archaic Indo-European feature that occurs in Sanskrit and Latin, although not in that particular word; or just cite a full paradigm representing regular verb conjugation: that's enough!"

PN: How does the reaction to your American Indian classification compare with the reaction to the African classification when it was first presented? It's true that your African classification has now become the standard point of reference, but at the time it certainly did have its critics, didn't it?

JHG: That's right.

PN: Compared with the American Indian situation, however, weren't there more people who accepted the African classification quite readily at the very beginning?

JHG: This is probably so, but for a variety of reasons. There are usually very few in the scientific community who know all the data that one is using. I've discovered that many people accepted my African classification but said, "The results are correct, but he didn't use the right methodology; now we're going to use the right methodology and prove that he's right" - which is a strange way of approaching the whole thing.

I think that there were irrational factors that ultimately worked in my favor. At the time that I did the classification, people did believe in a number of very broad groupings in Africa such as Sudanic, Hamitic, and so on. It's just that I felt they had been arranged the wrong way and that people had allowed nonlinguistic considerations to influence their thinking, for example, on the separate status of Semitic and the questionable position of Chadic, which people really hadn't looked at. When I produced my classification, the most articulate critics were the British. To my surprise, people like Tucker $^{5}$ and Guthrie ${ }^{6}$ did not so much defend the previous classification-which really represented the work of

5. Archibald N. Tucker (1904-80), professor of East African languages at the School of Oriental and African Studies.

6. Malcolm Guthrie (1903-72), professor of Bantu languages at the School of Oriental and African Studies, was considered the leading Bantu scholar of his time. His magnum opus is Guthrie (1967-7I). For an interesting discussion of the SOAS reaction to Greenberg's ideas concerning Bantu prehistory, see Flight (1988).

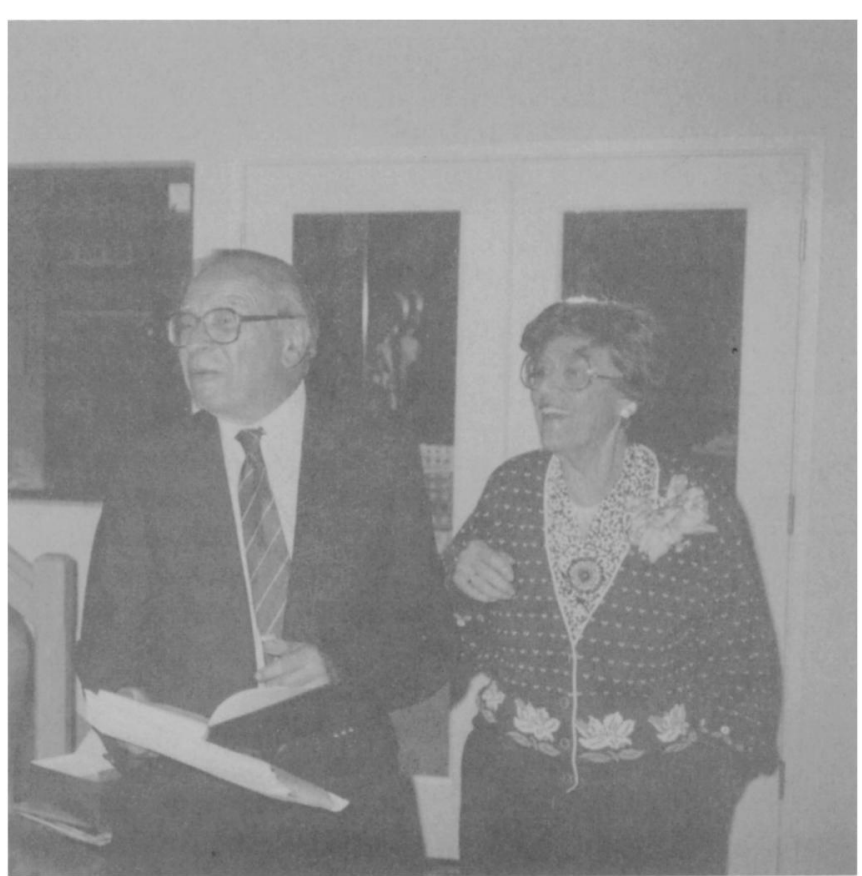

Joseph and Selma Greenberg at his 75 th birthday party. (Photo Merritt Ruhlen.)

two outstanding people, Westermann ${ }^{7}$ and Meinhof ${ }^{8}-$ as begin to talk very much like the present American Indianists: "No, we can't arrive at conclusions about these things; there are probably hundreds of quite separate groups; etc." Take Tucker and Bryan's Non-Bantu Languages of North-Eastern Africa [1956]: you would think that anyone with a modicum of observational alertness, after reading sketch after sketch, would notice enormous resemblances-let's say, in regard to NiloSaharan -in the grammatical structure and even in the few words that they cited. But they went back to a kind of nihilistic attitude that you couldn't classify because it was all so difficult and there were probably God knows how many groups. On the other hand, one has to realize that Americans were new to the business of African studies. It hardly existed in the United States previous to World War II. American scholars thus came into a field which was dominated mainly by British- and French-trained scholars. Therefore, in a quite irrational way, many people who didn't understand the first thing about language wanted to believe that this young American was right as against the stodgy British and French.

\section{PN: And the Germans?}

JHG: Including the Germans, who were also identified with colonialism, and so on, all of which had nothing to do with a scientific case.

PN: Going through The Languages of Africa [Greenberg I963a] in one of my classes, students commented that

7. Diedrich Westermann (1875-1956).

8. Carl Meinhof (1857-r 944 ). 
the matter of supposed Hamitic connections seemed to come up in every chapter. Was this a major linguistic question at the time, or did you have philosophical or personal feelings about the cultural/historical/racial nature of the Hamitic concept?

JHG: As I recall, I did work out my classification initially in reconsidering Meinhof's extended form of the Hamitic theory and the status of Hamitic as a valid linguistic unit [see Meinhof 1912]. The consideration of Fulani, for example, helped me in working out the notion of Niger-Congo. Similarly, looking at Masai enabled me to get a clearer picture of Nilotic and ultimately of Nilo-Saharan, and Hausa contributed to the development of ideas about Chadic. If my book appears to be, as it were, an extended critique of Meinhof, one must remember that Meinhof, who was saying the most things that I didn't think were true, was a major figure at the time, and his ideas on African classification [Meinhof I915] were very influential. They were adopted, for example, in books like Alice Werner's The Language-Families of Africa [1925], which I was given to read as a graduate student in a course I took on Africa. Whereas people expressed some degree of scepticism about Meinhof's views, particularly about Fulani-the least tenable of his claims-, on the whole they were taken very seriously. As I began to look at the matter, what struck me was the extent to which people were being misled by labels. Once you call something NiloHamitic, you feel that it is different from ordinary Nilotic; but if you just had the languages in front of you and they weren't given labels, you wouldn't see anything all that special about them, apart, perhaps, from the typological observation that a lot of these languages (for example, Masai and Turkana) have sex gender.

PN: So it wasn't the idea espoused by your late colleague Saint-Clair Drake [1959] that Hamitic was a politically and socially dangerous myth?

JHG: Well, it's true that I put in a few things regarding racism, because it was so obviously motivated by racist considerations; but I don't think that the Hamitic issue dominated the book. For example, a central question I dealt with was the position of Bantu among the languages of Africa, which had nothing to do with the Hamitic problem.

PN: One of the things I pointed out to my students that they found surprising was that Bantu appears in your index as if it were a single language, whereas the names of specific languages such as Swahili and Zulu and Kikongo are absent.

JHG: This was simply because there were other good sources for the inventory of individual Bantu languages.

PN: So the purpose wasn't to be provocative by downgrading the Bantu family to the status of a single language?
JHG: Oh, no, it was simply a practical consideration. As I began to think about these things, it was very reasonable that if languages such as one finds in the Bantu group are not very different from each other, they couldn't have differentiated very long ago, and therefore there must be some relatives around, which might be very small, unimportant languages. I guess that's where my anthropological background played a role-what I call linguistic democracy. From the point of view of language history and classification, it doesn't matter how many people speak a language: in determining relationships, the essential thing is to look at the linguistic evidence and not pay attention to extraneous factors.

PN: If I may, let me turn back to the American Indian language question and pick up on what seems to be a methodological or theoretical inconsistency in what you have done. One of the strengths of your African classification-one could say the key element, methodologically-was getting away from culturally and physically based linguistic classifications; your book was a reaffirmation of the independence of race, language, and culture. But very often now, in seeking support for your American Indian classification, you bring up what people are doing in the field of dentition, what the physical anthropologists have come up with, and so on. Isn't there an inconsistency in using the physical-anthropological/cultural evidence when it's useful and ignoring it when it's not?

JHG: No, I don't think so. I have never used the findings of other fields as an argument for the correctness of the classification as such: it was arrived at in virtual ignorance of what had been done in the other fields. One of the things I took for granted was the dictum that one classifies languages on the basis of linguistic evidence only, so in the first chapter of my book I think that I might not have even bothered to mention it. I do not believe, for example, that the concordant results of the studies of dentition [see Greenberg, Turner, and Zegura I986] and population genetics show that my classification is right. It's just a happy result-which, in a sense, is not quite as irrational as rooting for somebody just because he's American and not British or French or because he seems to be antiracist because of what he said about Hamitic. If a physical anthropologist who doesn't know the linguistic data says, "Well, Greenberg must be right," because he in turn is looking for support for his physical classification, that's just the nature of science-which is that one wants to see things fit together.

Having emphasized the point that language classifications such as I have done are based strictly on linguistic evidence, I should add that a high degree of correlation among physical, archaeological, and linguistic data might be expected in areas of new settlement. In the Americas, if you think of one group coming in and then some thousands of years later another group coming in, they are sure to have been very different culturally and to have come from different parts of Asia with different 
artifacts which would distinguish them archaeologically. A situation pretty much like this did exist in southern Africa, where the Bantu-speakers, who represented a new settlement, show a kind of archaeological homogeneity and thus archaeologists don't have any difficulty in identifying Bantu as opposed to Khoisan sites. So in the Americas, when you find a convergence of results from linguistics, archaeology, and physical anthropology, you can't say that it doesn't strengthen the case for my classification: I think it does strengthen the case.

PN: You've been talking about philosophical and psychological issues in science as well as the strictly scientific ones. I was wondering whether you agree that there's such a thing as having a feel or intuition for one group of languages as opposed to another. You've done classifications of American Indian, Austronesian, African, and Eurasian languages. Did you find that working on African languages, for example, was easier and that your hunches came faster than in the case of other language groups? Or does it not matter for you?

JHG: I don't think it really matters. What does matter, from a practical point of view, is that, starting out as an Africanist, I was much more aware of the sources. That is, the purely bibliographical side of it is difficult when you start working in a new area. And also, you're not part of the network of people who have been sending each other their most recent publications. As it turns out, however, from the point of view of classification, even old vocabularies and old grammars, and so on, are really quite useful. You can make a lot out of a small amount of evidence if you put it in a broad enough context.

PN: Do you really feel confident on this point? As you know, one of the arguments some of your American Indianist critics have used is that as an Africanist you may have understood that area but you are not a real American Indianist and thus you have gone astray this time.

JHG: Well, that's a strange argument, because as a matter of fact, when I began the African classification, I was just a tyro. The only language that I knew at all well was Hausa, on which I had done a few minor phonology articles [e.g., Greenberg I94I], and that I only knew in a sort of practical way. ${ }^{9}$ At the time I really knew very little about any of the other African languages. It was reported to me that someone said, "What right does he have to classify American Indian languages when he hasn't done any fieldwork on them?" And my answer to that would be: "What right did Sturtevant [1942] have to classify Hittite when he had never encountered a speaker of Hittite?"

9. Greenberg's fieldwork in 1939-40 was among the Hausa in northern Nigeria.
PN: I guess that you can carry this to a logical extreme. Let's go back a minute. You mentioned your very early work on Hausa. Your Ph.D. dissertation work was on Hausa religion. Am I correct?

JHG: That's right.

PN: How did you get into that? I mean, we often think of you not as a fieldworker but as the quintessential New York City library scholar, if I might be allowed to describe things in those terms. What were you doing out in the bush in Nigeria?

JHG: Well, you know, one's life is largely affected-but I think not completely determined-by accident. I got into anthropology as an undergraduate at Columbia. I hadn't actually heard of anthropology until-I think it was - the summer before my senior year, when I read a popular book on anthropology. I noticed that a course was being given by a man named Alexander Lesser, ${ }^{10}$ who had worked on Pawnee, so I took it. I also began to hear of a famous man named Franz Boas who was giving a course on American Indian languages. Now, I had always been fascinated by languages, as far back almost as I can remember-from the time that I studied Hebrew in Hebrew school through high school, and so on. I even had the habit of studying languages on my own. So when I took the course in anthropology, I also audited the course given by Boas on American Indian languages. I was fascinated by the extent to which they were different.

At that time there was a controversy between Boas and Sapir about the classification of American Indian languages. Evidently Lesser, who was one of Boas's students, saw in me-although I was only a senior at the time-someone who would be able to write an important article which would show that Boas was right. (When I think of it now, it's almost absurd.) Now, I really knew very little about American Indian languages, mostly from the grammars that were in the Boas handbook of American Indian languages [Boas I 9 I I-38], but some obscure instinct told me that Sapir was probably basically right. With the gumption of youth, I told Lesser, "I can't write this article, because I think in all probability Sapir is correct." Later, of course, I came to that conclusion on a much broader basis.

At any rate, when I took the course in anthropology, which was a large undergraduate course, I was supposed to write a term paper. Since I had studied Arabic on my own and I knew there were Arab travelers who had been in the Sudan and who had written about West Africa, such as Ibn Battuta [see Dunn 1986], I said to Lesser that I would like to write a paper about that. His answer to me was, "That's not a paper; that's a life work." Then he asked, "What are you going to do when you gradu-

Io. For a biographical sketch of Lesser (1902-82), see Parks (1985). A selection of Lesser's papers with an introduction by Sidney Mintz is to be found in Lesser (1985). 
ate?" With the heedlessness of youth, I had the idea in my head that I would become a medieval historian because I knew Latin and Greek and Arabic and Hebrew, and so on. But in fact I had no idea where one would get support. There was very little in the way of graduate fellowships in those days; we're talking about the late I930s. And he said to me, "Have you ever thought of going into anthropology?" I said, "No." He said, "You know, you can do linguistics and anthropology, as you see Boas is doing. There's such a thing as anthropological linguistics. And with your interest in Africa you should go to Northwestern and work with Herskovits." Social Science Research Council?" I said, "No." He said, "Well, they're giving a small number of fellowships now in the social sciences." There were, I think, eight of them. And he said, "If you apply for that, I'll get you a letter from Boas, and I'll get you one from Ruth Benedict, too." So he took me into Ruth Benedict's office. Of course, she had no interest in language-her field was personality and culture. I can't remember what I said to her or what she said to me. All I know is that after I came out, Lesser said, "She'll write a letter for you."

\section{PN: You hadn't known her before then?}

JHG: That's right. Much later I was told by Mortimer Graves, the director of the Social Science Research Council, "We pay no attention to letters from Boas; he'd write them for anybody." At any rate, I had always assumed that a letter from Boas was powerful and that I got the fellowship because of him. Interestingly enough, one of the other eight fellowship recipients was Charles Hockett, who went to Yale. ${ }^{12}$ I envied him greatly because he was going into linguistics, which is what I really wanted to study. So in my second year of graduate work at Northwestern, since the fellowship was not from Northwestern but the Social Science Research Council I got permission to spend a year at Yale. I think all my registered courses there were in anthropology, but I did take a few courses in linguistics. The one I can remember most was Leonard Bloomfield's course on Comparative Indo-European, which I audited.

Actually, I was at Yale twice; the other time was in 1940-4I before I was drafted into the army. I got an SSRC fellowship that enabled me to go to Yale for a quarter, at which time I encountered a rather different group of people. That's when I met George Trager, Bernard Bloch, and Benjamin Lee Whorf. ${ }^{13}$

I I. Melville J. Herskovits (1895-1963) and Northwestern University are rightly considered the father and the original home of Africanist anthropology in America. Greenberg's biographical sketch $(197 \mathrm{I} b)$ is an exceptionally warm tribute to Herskovits as a teacher and a scholar.

1 2. Hockett, now professor emeritus at Cornell University, went on to become one of the leading American structuralist linguists in the postwar period.

1 3. Bloch, for many years the editor of Language, and Trager were important figures in the American structural linguistics tradition. Whorf is best-known for his innovative ideas concerning the relationship between language and thought.
PN: So that was your Yale connection. After your year there as a graduate student, did you return to Northwestern?

JHG: That's right, the following year I went back to Northwestern. And then the next thing that you were supposed to do if you were an anthropology student was to do some fieldwork. So I went out into the field, and I came to the conclusion that, while I wasn't a bad fieldworker, I wasn't a brilliant one either and that this was just not the thing I was best at. I did my dissertation on Hausa religion [Greenberg I947], and I'm still interested in it. I do know a fair amount about Islam. For example, I recently wrote an article for a Festschrift for Robert Politzer, which hasn't been published yet, in which I compared the foundations of Islamic law with classical grammarians' notions about correctness in language and pointed out that in both cases the problem is to determine what are the fundamental ways of justifying a norm. It turned out that there was a remarkable parallelism that allowed one to equate one with the other. Then I turned to Arab grammarians, which was something I'm more at home with, and found that the two main schools in regard to what they called the science of grammar had considered these questions quite carefully. There was one school which in a way could be equated with modern sociolinguistics and another school that with regard to its spirit was very similar to that of generative grammar.

\section{$\mathrm{PN}$ : Oh, really? In what way?}

JHG: They just stuck with Arabic, and they wanted to explain everything from Arabic within Arabic, sometimes in ways we would now consider fanciful. But they often supplied elements which were not there, or they said that the word order was really different from that which appears on the surface.

PN: You mean that they had the idea of an ideal word order as opposed to what actually occurs?

JHG: That's right. In fact, if Chomsky wanted to look for predecessors, I think that he should really look not to Cartesian linguistics [see Chomsky I 966] but to the schools of Arabic grammar. Actually, it is difficult to know about them, since there's very little that's come from one of the schools and nothing directly from the other, but we do know in outline what they were like. What's called the Basra school is the one which was closest in spirit to the generativists. I would also say that this was true of a lot of medieval European linguistics, especially the school of the Modistae. I don't believe the school of the Modistae was influenced by Arabic grammar, but in spirit it was very similar. For example, it concentrated exclusively on Latin, just as the Arab grammarians concentrated on Arabic. In the Middle Ages, the grammarians paid no attention whatsoever to the languages that they spoke all the time. It was as though it had never occurred to them that their own 
languages had rules or that they were of any interest. The only thing they were interested in was Latin. One might say, in effect, that it wasn't until the first development of historical linguistics towards the end of the I 8 th century and the beginning of the I 9 th century that linguists ever considered more than one specific language.

PN: Going back to your field experience, one thing you learned was that you didn't want to be a fieldworker. But do you feel that having had that experience in any way influenced or affected your outlook as, let's say, an anthropological linguist as opposed to a formal linguist?

JHG: Well, you have to realize that that distinction existed even at the time. I believe it was not so much my fieldwork or my experience with Hausa that did it as the fact that my training as an anthropologist at a time when anthropologists tended to look for broad historical syntheses-which they don't any more-made it almost self-evident to me that the way to understand human language was to look at the variation among human languages and see what the limits of those variations were. For me, the big insight came when, through contact with psychologists, questions about language universals began to get raised. I was one of the first to become involved in a by now famous seminar in psychology and linguistics at Indiana University in 1953, which was organized by the Social Science Research Council and which produced a book which, for want of anything else, became a textbook for psycholinguistics for a long period after that [Osgood and Sebeok 1954]. Now, after that they wanted to have a conference on language universals [see Greenberg 1963c]. The psychologists said, "We're not interested in this purely technical aspect of how you analyze a language, how you segment in order to get morphemes, and so on. We would be interested in knowing what human languages are like. What's universal in human language? What's diverse? How can you explain the diversities?" They raised questions of that sort. And then the realization came to me that, if we applied the methods of the structuralists at that time, what we would end up with was hundreds and hundreds of grammars, and it was not clear at all what the next step could possibly be. The enormity, in a way, struck me, and I said to myself, "All this is just methodology. It doesn't tell me anything about what languages are like." It was then that I began to realize that it was possible to produce order over the whole area of the seemingly capricious and enormous variations of language if you concentrated on certain obvious things. In addition to the relatively small group of absolute universals which had to do with the structure of language, I discovered that there are an enormous number of relations among linguistic variables which are usually most easily stated in the terms of implicational universals.

PN: And so that's what got you into the area of universals?
JHG: Yes. Although I think it might have seemed original then from the point of view of linguists, it was not all that original from the point of view of anthropologists. The cross-cultural survey had been founded at Yale, and in fact they even had a rubric for language, though it was very sparse. Actually [G. P.] Murdock, the anthropologist who was most active in and director of the survey, knew me, and he said something like, "It's absurd to have language as just one little section. What we really need is something like the HRAF [Human Relations Area Files] which has to do with language." And it just seemed natural enough to me that one would extend the broad comparative approach to include language.

When I got into the word-order business, my anthropological background again stood me in good stead. I am sure that if I had not cited Pater Wilhelm Schmidt in my word-order article, there's hardly a linguist who would have caught me on it. But I was perfectly aware that he wrote Die Sprachfamilien und Sprachenkreise der Erde [1926], in which he made a great deal of the position of the genitive and showed that it was related to certain other things. Subsequently I discovered a lot more connections. But at least it made me realize that there was something here which was very orderly, although I obviously rejected Father Schmidt's interpretation of it, which was in terms of a whole series of early migratory cultures. (Wherever he found languages which put the genitive before the noun in different parts of the world, he thought it was because they were the same original culture, which he called a Kulturkreis.)

I might say one other thing that came out of the African classification, and that is that outside of the requirement that one should only consider linguistic evidence and not external cultural and physical evidence was the notion that one should make a clear distinction between typological and genetic criteria. That this had not been done, which led to a lot of problems with earlier classifications, was because people were unaware of how fragile some of these typological things were historically. Besides that, they always involved a relatively small number of possibilities. How much can you make of Genitivstellung-the position of the genitive-when there are only two possibilities? If you used that, there would be two language families in the world: those that put the genitive before the noun and those that put the genitive after the noun. Nevertheless, I said to myself, "These patterns must have some importance, even if the importance is not for historical comparison." So I was in a way ripe for moving into the area of typology.

Also, I might say, at first I was impressed by the wisdom of the American establishment-pre-Chomskyan descriptive linguistics, as it has been called-and viewed that as very scientific. But when I came to Columbia, I began to come in contact with members of the Prague school, who quite rejected it. At first these Prague people struck me as very sloppy and without a real method. This was often, by the way, the complaint about typology. 


\section{PN: When was this?}

JHG: The early 1950s. Roman Jakobson was at Columbia for a while before he went to Harvard, and André Martinet was there. The Linguistic Circle of New York, as it was called, was run by refugees from the Prague school. They asked me to be editor of Word for no other reason, as far as I can make out, than that they needed somebody who knew English as a first language. Anyway, my first reaction to the Prague school was that this was all very impressionistic and not rigorous. However, I began to see that they had certain insights which couldn't otherwise be obtained, for example, those with regard to markedness theory, so I began to take them seriously.

PN: In looking back at the work of the structural linguists, who later came to be called the postBloomfieldians, it appears to me that the generativists were very much in that tradition, as opposed to a typological or Praguean tradition. I mean, the generativists claim to reject it all, and yet their scientific objective appears to me to be very similar to that of the formal structuralists.

JHG: Yes, I've been struck by that more and more. The fact is that once I got into typology it turned out to be extremely fruitful; and ultimately a good many other linguists also began to use typological methods, so it's now quite a respectable field with a fairly considerable literature. I kept up with generative grammar for a while, and then there were so many changes in it and it required so much attention that I didn't pay much attention to it. However, recently I decided I ought to catch up a little. So I've been looking at a textbookbecause that often is a good way of getting at these things - by a man named Radford [1 988], and I've discovered the same kinds of arguments for distribution that were used earlier - to the point where they cite Bloomfield and Rulon Wells ${ }^{14}$ in regard to constituent structure-, the same appeals to simplicity and economy and also the same disregard for historical change. In fact, one can't see from generative grammar why a language should change at all. By making virtually an absolute distinction between competence and performance, you can never know how a language would change, because every time there's variation they say, "Oh, that's the sort of thing that belongs in a field like sociolinguistics." They tolerate it, but honestly they probably don't think it's of any great importance because it really has to do with performance. But ultimately changes which will occur in performance can be studied systematically, which was the great contribution of [William] Labov, the sociolinguist. Of course, this should have been no secret. Long before that, historical linguists in the I 9 th century knew very well that it was from variation within the speech community that

14. Wells is a Yale linguist and philosopher whose work typifies the American post-Bloomfieldian tradition. new forms develop and that language is in constant change.

Ultimately, however, I think that generativists and typologists have the same goal-at least I would like to think that they do. And if it is so, it is because there is no better material than language for understanding how the human mind works. That's what we're really interested in. We're not interested in defining what is a possible human language by putting down a set of formal rules. I find that really fairly unexciting; it's just a byproduct of what I do. It seems to me that there is as much psychology in change as there is in looking at language - in what I consider an artificial way-as a sort of static state, with something that's very rigid and inborn in the child that is supposed to project its form onto the language. What I'm saying is not fair, in a way, because people look at language very differently-I can't understand the way they look at it, and they probably can't understand the way I look at it-so one is likely to distort, maybe, and exaggerate. However, I do have the impression that they are looking at language as some kind of fixed thing, which is innate. Now, I'm not denying innateness at all-that's another problem-but I don't think that what is innate can possibly be kinds of highly specific structures. Where the human mind shows itself is in how it interacts with given linguistic material, because it is impossible to shake off history. Everybody encounters an existing speech community with an existing language, which is the result of historical development. What people do with that inheritance really shows how they work in a psychological manner. Take, for example, an old-fashioned concept like analogy: why do human beings analogize? Why do elements which have concrete meaning become the source of grammatical elements? That's now a very popular field of study-grammaticalization [see, e.g., Heine and Reh I984]. It's easy enough to make up a slogan, but if I were younger and had time to go back into psychology in the way that I did 30 years ago, I would say that what we need is a dynamic psychology. The way the mind works shows itself in how it works on material. And this, in a way, is an evolutionary adaptation. Language must constantly adapt because certain quite natural changes produce consequences in the system which, at a particular moment, may seem unnatural; but these aberrancies do get ironed out in the course of historical change.

PN: If language is an ideal system with an ideal speaker/ hearer-if it's all perfectly in balance-, it should never change.

JHG: Exactly. Why should it ever change? In that case, languages would never split off, and we'd all be speaking the same language. But that clearly has not happened. Well, as I said, languages adapt: they adapt internally, and they also adapt externally. If you take what some people are now calling a functional approach, which would include all nonformalist approaches-some of them concerned with discourse, some with typology, some with sociolinguistics-what they all have in com- 
mon is that they are willing to look for factors outside of a language. From the point of view of the strict formalists, it is as though one had some kind of fixed form which can't be explained in any sort of external terms at all-even in regard to other activities of the human mind. Surely the capabilities of the human mind in other areas, not just speaking, are involved in language also. The result is a kind of rigid way of looking at the whole thing. My own feeling is that it's a dead end; but unfortunately there are vast numbers of people who have been trained in generative grammar, and there is so much effort expended in doing it, and there is so little tendency on the part of human beings to question fundamental assumptions-I know how slow I was to begin doing so-that I think people will just continue carrying on as they have been doing. Right now, of course, generativists are finally getting interested in crosslinguistic variation. Many people say that this is due to the influence of typology, and it's pretty clear that this is so. On the other hand, they go about it in their own characteristic way, which one can truly call "inductive" in an unfavorable sense. (I should add, since I've been criticized as being purely inductive and not having any theory-and anybody who's read me knows that I talk quite a bit about theory-that there's a lot of theory in typology.) What they do is just look at a very small number of languages which they happen to know about, or a friend of theirs knows about, or they happen to be working on. Then they produce highly specific theories which are supposed to explain certain phenomena in language; but anybody with a reasonably broad knowledge of languages knows that it's not going to work on the next language one looks at, which it doesn't. So they get out of that by modifying the theory a little bit, that is, by saying that it's a new parameter. But they have no systematic theory about what the parameter should be, how many parameters there are, how they're organized, just how they should be ordered, or why certain ones are favored. So whatever they say is irrefutable. In that regard typologists are certainly ahead of them, because they've been looking at languages in an empirically sensible way and doing comparisons for, well, maybe about 30 years, at least since my word-order paper [Greenberg $1963 b]$.

PN: You've ascribed some elements of your approach to your anthropological background. One of the things that has struck me with the development of autonomous linguistics departments has been the increasing separation of the two fields. You get one group of people who are being trained in linguistics departments, where the approach tends to be very formal and very theoretical. And to the extent that people now do any linguistics in anthropology departments, it's really supposed to be some kind of hyphenated linguistics: sociolinguistics and the like. So you don't have people coming up with the kind of training that you might have had-what people in the Boas-Sapir tradition would have called anthropological linguistics. There seems to be a gap in the middle that is not being filled now.
JHG: I believe that it is just a part of tradition that if you happen to be working on languages of specific American Indian groups or on some unwritten African languages-at least ones that were only written in the recent period in Africa and not literary languages like Hebrew or Arabic-you are likely to be in an anthropology department. Some of these anthropological linguists have been strongly influenced by modern linguistics in that they do have this sort of formalist training. But what they lack, let's say, in regard to American Indian languages, for example, is a broad view of what languages are like-even what American Indian languages are like. I think there is here a sort of hidden metaphor. Maybe science is like an assembly line in a factory, where you turn out a better car if one guy is very fast at putting a certain nut and bolt on and another one is involved in making the wheels and putting the wheels on, and somehow some finished product will come out of that-so there is an inevitable specialization in science. In the Middle Ages and up until probably the 17 th and I 8th centuries, scientists were called philosophers. (Philosophy is just what's left over after all the various sciences branched off, right?) So after you had, let's say, biology as a separate science, you then had people who specialized in paleontology and other people who specialized, let's say, in population genetics, and so on. It seems that the natural way to go in science is specialization. However, there is an evil to specialization when carried too far, and that's quite obvious. What has struck me about population geneticists is that they don't quite have this narrowness of view. Someone like CavalliSforza is not blamed because he is willing to compare the genetics of populations in a large number of groups all over the world and try to arrive at a comprehensive view of what they are like [see Cavalli-Sforza et al. I988]. This seems, still, quite natural to biologists. If they went on the way linguists do, there would be people who would become experts on Hungarians, for example. (By the time we'd mapped all the genes there would of course be an enormous amount of work to do for any particular population.) They would know everything about the genetic pool of Hungarians, but only occasionally would they peek at any sort of results that had to do with people like Czechs or Austrians. So what would the result be? I've found again and again that the answer to a question doesn't lie in looking at the question more and more closely over a longer and longer time. The best approach is to put it aside, and someday, when you're looking at something very different, it'll turn out to be relevant.

Now, you know the story of Hausa final long vowels. ${ }^{15}$ That's a perfect example. I was puzzled by it. I don't think any synchronic analysis can do anything but simply restate the facts in fancier and more abstract terms. But from a very different problem, namely, the develop-

I 5. In Hausa almost all common nouns, excluding recent loanwords, have a long final vowel. The question is why proper nouns and corresponding denominal adverbs invariably end in a short vowel. 
ment of the definite article and the problem of class markers in Niger-Congo languages, the answer was a kind of offshoot. It suddenly occurred to me that when you get this last stage of the article, it's going to show just about the same characteristics as you have for the long vowels in Hausa. And I think that's now pretty well accepted, and people are discovering stage 2 and stage 3 articles all over the world but particularly in Africa, where they seem to be endemic. ${ }^{16}$

PN: I certainly agree with you on this. As a comparativist looking at other Chadic languages, you can't help but note that common nouns normally end in a short vowel, contrary to the case in Hausa. But if you didn't have a comparative perspective, it would never occur to you that there was anything unusual about Hausa final long vowels.

JHG: That's right, you would just take the facts for granted.

PN: You were talking earlier about your time at Columbia as a student. Later, I understand, you worked there in the Anthropology Department. For how long a period was that?

JHG: Let's see, I came in 1948 and I left in I962, so that was 14 years that I was at Columbia.

PN: During that time, wasn't Columbia considered to be one of the major centers of linguistics in America?

JHG: Yes, at first, but for a number of reasons its linguistics department didn't flourish. There was a series of unfortunate accidents. One of them was that Jakobson left for Harvard. Another was that Uriel Weinreich, whom I considered a very promising scholar with a first-rate mind, someone who would have made a difference-he was in some of my classes to begin with, and I was on his doctoral committee-died, unfortunately, of cancer at an early age. ${ }^{17}$ Another unfortunate thing was that Weinreich's most important student, William Labov, who was the virtual founder of modern sociolinguistics, went to Pennsylvania. And then, it's probably fair to say, my leaving for Stanford didn't help the Columbia linguistics program, either. So it's remained a sort of heterogeneous collection of scholars. I don't mean to imply that the individuals remaining there are not good scholars, but it's never developed into a coherent program or department.

PN: In a fairly recent note in Language [Halle I988] Morris Halle mentions tension at Columbia during that pe-

I6. Greenberg's model whereby articles go through parallel historical stages and eventually become incorporated in noun stems is presented in Greenberg (1977). In that paper, Greenberg proposes-correctly, it appears-that final long vowels in Hausa common nouns are vestiges of former articles.

17. Weinreich (1926-67) is best-known for his book Languages in Contact (1953), which has gone through a number of editions and has become a classic in the field. riod between the European émigrés and the American structural linguists. Is there any truth to this, or is it a sort of revisionist history?

JHG: Oh, I think that this was true. In my case, I tended to be sympathetic to the Europeans, in the first place because I had an open mind at the time and second because I was not happy with American structuralism. I recall the summer of the Psycholinguistics Institute at Indiana, which coincided with one of the Linguistic Society of America Institutes. It was a very small seminar. There were just two or three linguists and two or three psychologists, and people thought in those days that information theory had a lot to offer, so there were one or two people in information theory. And it fell to my lot-and this is in the psycholinguistics monograph [Greenberg I954]-to explain linguistics to the psychologists. And as I did it, I said to myself, "I am describing procedures here which in fact don't work." I mean, I knew this. In fact, I gave a course on phonology at Columbia in which I pretty systematically destroyed all the existing theories that had to do with the definition of the phoneme. Morris Halle, by the way, was one of the students in the course. He was such a quiet student that I never realized that he was going to amount to very much - which he evidently did. ${ }^{18}$

Anyway, I began to see more and more in the broader Prague approach. I did this, I think, without getting into fights with anybody, but my thoughts just moved in that direction. What I also liked in the Prague school was its interest in historical matters, that is, what was often called "dynamic synchrony." Some of them tended to be typical structuralists, in the European structuralist as against the American structuralist tradition; but they were much more receptive to the whole notion of generalizing across languages, which is the sort of thing that led to my typological interest, and also the importance of diachrony, or linguistic change. I might say that after my first work in typology, what had struck me more and more was the importance of diachrony in explanation [see, e.g., Greenberg 1969]. If there is any achievement for which I hope I will be remembered, it will be that the development of typology has allowed one to look reciprocally at the relations between synchrony and diachrony and to put diachrony back into a central place in linguistics.

I think, by the way, that generativists simply don't understand what you mean by a historical explanation: that history helps to explain certain things about language. You know, the history of science is not that of a straight-line development and improvement, and I think something very precious was lost under the aegis of which modern linguistics as we know it developed, which was the revelation to people in the Igth century that if they looked at things in a historical context they would understand them better. For example, the generativists often talk about a peculiar language-specific

I 8. Halle, now professor of linguistics at M.I.T., became one of the most influential phonologists of the poststructuralist period. 
rule, and then they leave it to an indefinite future to see how it fits in. They say, "Someday we will discover an explanation." But often there is a very good historical explanation staring them in the face. Now, I would say that the specific historical explanation is not a final one. It raises still other questions, namely, if it's the result of a change, why do languages change in that way? Can we generalize about changes? Do other languages do similar things in similar circumstances? But until you understand the specific historical change and put that in context, you haven't gotten anywhere. You simply are unable to say anything except that in the distant future, somehow, these peculiar rules will be understood.

PN: Of course, once you understand why the situation became the way that it is, you can still approach it from a generative point of view. That is, you've ended up with this strange rule for historical reasons, and the question is, How do native speakers handle it?

JHG: Exactly. Very often if it is peculiar, that very fact shows that it's historically unstable. A rule that's peculiar is called peculiar because it occurs in very few languages of the world. And it's found only in a few languages because it can only arise from certain specific situations, and what's more, when it does come into existence, it's historically unstable. Otherwise you would find it in a lot more languages. But to understand what's going on at all, you have to understand the historical processes that produce this strange rule, which is often a by-product of quite understandable things in other ways. And you have to understand what people do to it in order to produce changes in it so that it no longer exists, which is the reason in the first place that it is a peculiar rule. In short, it can only arise in a few situations, and it can't last very long. Language is full of odds and ends like that. Everyone who's studied a language will find ragged ends.

That's another thing that never satisfied me about structuralism, including European structuralism, which is captured in the famous dictum of Meillet ${ }^{19}$ that language is something in which tout se tient ["everything hangs together"]. I said to myself, "There are a lot of things that don't hang together." For example, whether a language has a set of implosive stops has absolutely nothing to do with whether it has grammatical gender or not. There is no causal connection there, no matter how far one would seek. Any connection that one finds is simply the result of the fact that the languages happen to have the same historical origin or are spoken in a certain area in which both of these things happen to be popular and have spread. But that has nothing to do with a causal connection. The problem of the linguist is to find out what aspects of language are causally connected. And that's where I think typology has probably made its biggest contributions.

19. Antoine Meillet (1866-1936) was the leading French IndoEuropeanist and general historical linguist of his day.
PN: Let me ask something that's somewhat unrelated to what we've been talking about. I know that you are a musician and a music lover. Has this been strictly an avocation for you, or has it in any way tied in with your linguistic work?

JHG: Well, let me put it this way: I'm an auditorily oriented person. I can look at pictures, and so on, but the fact is that they don't do very much for me, whereas music I find exciting. To me it was a very real career choice to decide whether to become a professional pianist-which I may or may not have been successful at, I don't know - or to go into linguistics. It's occasionally had some relevance to what I do. For example, one of my things that I'll probably never write up in a published paper had to do with the way the melodic lines of folk music throughout the world reflect the natural intonational tendency to have a falling melodic line, just as the unmarked declarative statement in language involves a fall at the end. If you look at Western music, it is also like that. The general melodic line, to give it a little interest, usually goes up a bit in the middle, and then it falls at the end. That is, it has final cadences, and you still have final cadences in Classical music. However, there was a period that reached its height in Romanticism which reversed that; to get some kind of intellectual excitement in the music, you repeated a sequence, and you repeated it at a higher and higher pitch. If you take relatively short compositions, you will find that the highest note occurs toward the end. But this was very rare in the history of music. In folk music and in music which followed the period of Romanticism in Western music, there seems to be a perfect indifference to this increased raising phenomenon; rather, the highest note can occur anywhere, often relatively close to the beginning. So I made a statistical study of some preClassical music; I think I took Frescobaldi and Bach. Then I took typical Romanticists like Mendelssohn, and for modern music I took Bartok. It turned out that if I mapped a number of compositions-you have to take something relatively short, because in something very long, such as a whole symphonic movement, all kinds of things can happen-and it in fact worked out. I gave a little talk about that at the Humanities Center here some years ago, but I've never published it.

PN: Did you ever do anything on the relationship between musical sound and colors?

JHG: Well, this was an experience which, like so many things, was very vivid in childhood, and by now, since I discovered the system, is sort of intellectualized. Apparently a small percentage of the population has a strong association between certain pitches and certain colors. In our musical tradition we of course have the diatonic scale, and with me it was particularly strong. Any major and its corresponding minor-for example, A minor and $\mathrm{C}$ major-will have the same color association for me, but it will be much stronger for the major than for the minor. I discovered this as I studied the 
piano. I guess to have this experience the first requirement is that you have absolute pitch, and I discovered to my amazement that absolute pitch is a relatively rare phenomenon. I thought everybody had it.

PN: Oh, no. It's quite unusual.

JHG: I was studying with a very good teacher who had a studio near Carnegie Hall. Once in a while in her courses in musical theory, all her students-there were probably ten or eleven students-would be told to transcribe something which she played. I always transcribed the actual notes, whereas nobody else did. So she came to me and she said, "You know, you have absolute pitch," and she told me that only about I\% of the population had it. Well, I had already been discovering, before she told me that it was called absolute pitch, that I had very strong associations between particular keys, especially those close to $\mathrm{C}$ major in the circle of fifths. ${ }^{20} \mathrm{G}$ major, the next one in the circle of fifths, would be sort of yellowish, whereas D major was definitely orange, and A major was red. On the other hand there were the cool colors-F major, which was relatively colorless, B-flat, which was pretty definitely a greenish-blue, and E-flat, which was blue, and so on. Some of the experiences I had were very vivid. One day-I don't know how old I was, I must have been about I3-I was on the beach at Coney Island and I was looking at the sun, which is D major, orange. Suddenly the whole universe seemed to reverberate with a tremendous $D$ major chord, which I actually heard. Maybe it was an auditory illusion? I didn't know that there was any system to this for a while. On another occasion when I knew more about music theory, I just sat down and wrote out the associations, and I discovered that, though each one was a spontaneous association, they formed a regular system in which the color spectrum reflected the circle of fifths. Later I discovered that John Carroll, the psychologist, also had such sensations. We were at a meeting and somehow got talking about this, and it turned out we both had this phenomenon, so we compared notes. In general his was like mine, although mine really was more systematic, so we did a little joint article in a psychological journal about synaesthesia [Greenberg and Carroll I96I].

PN: What is the relation between tone languages and music? Since I always work on tone languages, I just assume that languages ought to be tonal; it seems to me only natural that pitch should be used linguistically. Now, two or three tones is quite common, but more than three seems to be rare.

JHG: That's right. It's very rare to have four levels, and then when you get a larger number of tones they are generally contour tones, falling, rising or something. It's

20. The circle of fifths refers to a representation of musical keys as moving clockwise in fifths adding sharps (C, G, D, A, and so on) and counterclockwise in fifths adding flats (C, F, B-flat, E-flat, A-flat, and so on). puzzled me, because it's clear that you don't have to have any great training in music to recognize a larger number of pitches than that. On the other hand, it might not be that easy. You see, when you speak you have to go from one of these pitches to another. So let us suppose that there was a language where the high pitch was on a G, and this was a language with, let's say, six levels (which may not exist anywhere in any of the languages of the world). Now, to be able to distinguish a drop from a sixth tone to a third tone, from a fifth tone to a fourth, or from a fourth to a second might not be all that easy. It might not be difficult for me, because I would hum a tune with it and I would know what note it was; but $99 \%$ of the population doesn't have absolute pitch. What they'd be judging is really the interval between specific tones.

PN: Well, you wouldn't really want language tone to be based on absolute pitch, because men and women and children don't speak on the same pitch.

JHG: Well, I can allow for relative pitch, too. For example, it used to bother me a great deal if I had a recording of a symphony, let's say, Mozart's Jupiter Symphony, no. 4I, which is in $C$ major, and it wasn't exactly right. If it sounded like B instead of $C$, everything would seem wrong to me. This doesn't mean that if you stopped the record at a certain point and asked what was coming next-I happen to know this music pretty well-I couldn't immediately continue in the relative pitch. It's just that everything seemed to be in the wrong color.

PN: At your retirement banquet at Stanford a few years ago, one of the things you mentioned in your informal talk was the importance of your Jewish heritage in your development as a scholar. You didn't elaborate then-it was almost a comment in passing - and I was wondering if you would like to say more about this now.

JHG: I think that it was just a feeling on the occasion that intellectual achievement was something that Jews had attained in the past. Nowadays, people are always talking about role models; well, there didn't have to be formal courses in Jewish contributions to science or philosophy for me to realize that this was true. There was a kind of unspoken feeling I got from my father and others that scholarly achievement was something to be respected. In the Jewish community you still had a sense that learning had a value as such and that the people who were most respected were the rabbis, the learned scholars, and so on. I think that some of this must have rubbed off on me, or I might have gone into something else.

\section{PN: Was your father a scholar?}

JHG: No, he was a pharmacist who wanted to become a doctor. He was an immigrant from Poland, who came over when he was about I 3 years old-they always ran away before being drafted into the tsarist army. Within 
two or three years of coming to this country he got a degree from the Columbia College of Pharmacy. He hadn't spoken English before, so how he did it is amazing. Now I wish that I had asked him more about it-it would have been a fascinating story-but when you're a child you just take it for granted. He had a drugstore, which he lost in the Depression, and then he became an insurance salesman.

He did have a spontaneous interest in languages, although it was completely undisciplined. He told me once that he regularly shined shoes in Warsaw for soldiers who knew German because he wanted them to teach him the language. He learned Russian in school, and Polish was spoken all around him. Yiddish was his first language; even later on in America he regularly read the Jewish newspaper.

\section{PN: Did you grow up knowing Yiddish?}

JHG: Only passively. I heard Yiddish when my father's family came to the house, which was as seldom as my mother could arrange it-she thought they were rather boorish. She came from a German Jewish family that felt culturally superior since they spoke good German rather than Yiddish.

PN: How about at the university level? Did you study Yiddish there?

JHG: No, I never did. It was only later that I became more intellectually aware of it through contact with Uriel Weinreich, who had a big Yiddish project.

\section{PN: And Hebrew?}

JHG: This I just studied in Talmud/Torah [Hebrew school], although I learned it better than most kids did, and I kept up an interest in it. My teacher gave me an Old Testament in Hebrew and English, which I still have at home.

PN: Are there any topics that I've forgotten to bring up today that we should talk about?

JHG: I don't know. I guess the decisive point in the development of my work was my word-order paper: everybody seems to have recognized the historical importance of that paper. That led to a line of investigation in which I came more and more to realize the importance of diachrony. Moreover, I came more and more to systematize the theoretical foundations underlying typology, which I think most typologists have tended not to do. That is, they have just proceeded to do typology, which is all right, but it makes it appear to nontypologists as though they don't have any theory-that they just look at random languages. The other thing that struck me is the importance of having very, very large samples. In classifying languages genetically I found that it is perfectly possible to classify a language with a small amount of data if you know a lot about a lot of other languages, because then you know what's diagnostic.
And in fact, Indo-Europeanists have worked that way. There are, for example, languages in Asia Minor, such as Phrygian, known from a handful of inscriptions, which Indo-Europeanists are sure are Indo-European just because they have certain diagnostic features, such as the correct endings for the first, second, and third person in the verb or the correct interrogative pronoun or one or two common words. So I got into the habit of looking very broadly. If somebody undertook to do a classification of African languages today, he would probably only want to look at so-called reliable material. He wouldn't want to look at old vocabularies and such, whereas I didn't despise anything. I probably intuitively had the spirit of a historian, because for the historian all sources are important and all sources are imperfect-it's just that certain sources are more imperfect than others. For example, right now I'm doing some work on numeral systems [e.g., Greenberg 1989]. I often want to look at earlier sources, because the things that I'm looking at are so delicate historically and so likely to change that one will often find that between a grammar written in I 830 or 1840 and a grammar written a hundred years later important changes will have taken place.

If you're going to do typological work, there are really very few generalizations which don't have some exceptions-which raises the question of sampling. If you're investigating something which all languages have-for example, all languages form questions, right? - you would have to look at the 3,000 or, as some people say, 10,000 languages that exist in the world. Maybe that's impossible; so you've got to have some kind of reasonable sample. That means you've got to look at every continent and have a look at every major group, and so on. On the other hand, if you're looking at something which is a restricted sort of thing and which isn't going to occur very often, I think that the best sample is the total sample, because the more things you look at the more you learn. There's hardly an example of a language which won't tell you something about something, even if the description of it is not good. There are people who would only be willing to use a description that was done according to a particular theory of grammar, but the theory of grammar itself has changed. So now a grammatical description in transformational terms written in the period before Aspects [Chomsky 1965 ] inevitably looks archaic, whereas a very good grammar written in the I9th century, like the wonderful grammar of Eskimo done by Kleinschmidt [I 85 I], will stand up at the present time. It's just a question of whether you get the language or you don't. In fact, you may be impeded by so-called theories of grammar, which will prevent you from saying things which you might otherwise want to say and which are important about the language. If you take a grammar done by a missionary who has spent all his life studying it, it will inevitably have certain defects if he's not properly trained; on the other hand, he will really know the language as against someone who breezed through on a field trip with the latest theoretical training but only a month or two to spend on it. 
PN: Do you have students or former students who are continuing this work, or has it been hard to produce people who have the necessary breadth? Your work has been characterized by the control of an enormous mass of material and masses of languages, and most people just don't have the background and training to do this.

JHG: One of the problems-and it may seem trivial-is that unless you read all the major research languages you're going to be handicapped. You know, you find graduate students today who don't read German; of course, some read French, but they don't read German. It's becoming more and more important to read Russian, because there's a whole area of the world in which virtually all the material is in Russian. Maybe there will be nobody after me for a long time who will relish the job of handling piles and piles of notebooks on all kinds of things all over the world. But I've had a few students who have considerable breadth. Certainly outstanding among them is Bill Croft [see Croft 1990], who is interested in a broad range of topics concerning universals and who looks at a lot of languages in order to work on it. Another very good student was Suzanne Kemmer, whose major interest is diachronic typology. Then there is Keith Denning, who finished up his Ph.D. a couple of years ago with a thesis dealing with interactions between vowel quality and phonation and general problems of comparative Nilotic. ${ }^{21}$ His main work is on phonology, but he's interested in a lot more than that. So, you see, I've had some good students, but I have never been a very good player of academic politics and thus never tried to appoint people who were my own students.

PN: You mean you never built a school as such?

JHG: That's right, and I never made sure that they got appointed to other places, and so on. I suppose I may have suffered from that. But I think it's true to say that most of the people who have been influenced by my work have been influenced not because they were students of mine but because they read some of my things and it got them interested in my approach and in my ideas.

PN: As you know, I myself belong to this camp of indirect students. From the time I first met you in front of the New York Public Library some 25 years ago-I'm sure that you've forgotten-I have continued to be challenged and inspired by your work.

\section{References Cited}

BOAS, FRANZ. I9I I-38. Handbook of American Indian languages. Washington, D.C.: Government Printing Office.

CAMPBLL, LYLE. 1988. Review of Language in the Americas,

2r. Croft, Kemmer, and Denning received their Ph.D.'s at Stanford in 1986,1988 , and 1989 , respectively. by Joseph H. Greenberg (Stanford: Stanford University Press, I987). Language 64:59I-6I5.

CAMPBELL, LYLE, AND MARIANNE MITHUN. Editors. I 979. The languages of Native America: Historical and comparative assessment. Austin: University of Texas Press.

CAVALli-SFORZA, LUigi lUCA, A. PIAZZA, P. MENOZZI, AND J. MOUNTAIN. I988. Reconstruction of human evolution: Bringing together genetic, archaeological, and linguistic data. Proceedings of the National Academy of Sciences $85: 6002-6$.

CHOMSKY, NOAM. 1965. Aspects of the theory of syntax. Cambridge: M.I.T. Press.

- 1966. Cartesian linguistics. New York: Harper and Row. CROFT, WILLIAM. I990. Typology and universals. Cambridge: Cambridge University Press.

CROFT, WILLIAM, KEITH DENNING, AND SUZANNE KEMMER. Editors. 1990. Studies in typology and diachrony for Joseph Greenberg. Amsterdam: Benjamins.

DRAKE, SAINT-CLAIR. I959. Détruire le mythe chamitique, devoir des hommes cultivés. Présence Africaine 24-25:2 I 5-30.

DUNN, ROSS E. I 986. The adventures of Ibn Battuta: A Muslim traveler of the I4th century. Berkeley and Los Angeles: University of California Press.

FLIGHT, COLIN. I988. The Bantu expansion and the SOAS network. History in Africa I 5:26I-30I.

GREENBERG, JOSEPH H. I 94 I. Some problems in Hausa phonology. Language 17:316-23.

. 1947. The influence of Islam on a Sudanese religion. (Monographs of the American Ethnological Society ro.)

New York: J. J. Augustin.

- 1954. "The linguistic approach," in Psycholinguistics: A survey of theory and research problems. Edited by C. E. Osgood and T. A. Sebeok, pp. 8-I9. Baltimore: Waverly Press. . 1960. "The general classification of Central and South American languages," in Men and cultures: Selected papers of the sth International Congress of Anthropological and Ethnological Sciences, 1956. Edited by Anthony Wallace, pp. 791-94. Philadelphia: University of Pennsylvania Press.

. I963a. The languages of Africa. Bloomington: Indiana University.

- $1963 b$. "Some universals of grammar with particular reference to the order of meaningful elements," in Universals of language. Edited by Joseph H. Greenberg, pp. 58-90. Cambridge: M.I.T. Press.

- Editor. 1963c. Universals of language. Cambridge: M.I.T. Press.

- 1969. "Some methods of dynamic comparison in linguistics," in Substance and structure of language. Edited by Jan Puhvel, pp. 147-203. Berkeley and Los Angeles: University of California Press.

- I 97 I $a$. Language, culture, and communication: Essays by Joseph $H$. Greenberg. Edited by Anwar S. Dil. Stanford: Stanford University Press.

. I 97 I $b$. Melville J. Herskovits. Biographical Memoirs, National Academy of Sciences 42:65-93.

- 1977. "Niger-Congo noun class markers: prefixes, suffixes, both or neither," in Papers from the Eighth Conference on African Linguistics [UCLA, April I-3, 1977], edited by Martin Mould and Thomas J. Hinnebusch, pp. 97-104. (Studies in African Linguistics, Supplement 7.) Los Angeles: Department of Linguistics, UCLA.

- 1986. On being a linguistic anthropologist. Annual Review of Anthropology I 5: I-24.

. I987. Language in the Americas. Stanford: Stanford University Press.

- 1989. The internal and external syntax of numerical expressions: Explaining language-specific rules. Belgian Journal of Linguistics 4:105-18.

. I990. On language: Selected writings of Joseph $H$. Greenberg. Edited by Keith Denning and Suzanne Kemmer. Stanford: Stanford University Press.

GREENBERG, JOSEPH H., AND J. B. CARROLL. I96I. TWo cases of synaesthesia for color and musical tonality associated with absolute pitch ability. Perceptual and Motor Skills 1 3:48. 
GREENBERG, JOSEPH H., CHRISTY TURNER II, AND STEPHEN ZEGURA. I986. Settlement of the Americas. CURRENT ANTHROPOLOGY 27:477-97.

GUTHRIE, MALCOLM. I967-7I. Comparative Bantu. 4 vols. Farnborough: Gregg Press.

HALLE, MORRIS. I988. The Bloomfield-Jakobson correspondence, I944-I946. Language 64:737-54.

HEINE, BERND, AND MECHTHILD REH. I984. Grammaticalization and reanalysis in African languages. Hamburg: Buske.

HROZNÝ, FRIEDRICH. I9I7. Die Sprache der Hethiter. Leipzig Hinrichs.

JUILLAND, ALPHONSE. Editor I977. Linguistic studies offered to Joseph Greenberg on the occasion of his sixtieth birthday. Saratoga, Calif.: Anima Libri.

KA UFMAN, TERRENCE. I990. "Language history in South America: What we know and how to know more," in Amazonian linguistics. Edited by David L. Payne, pp. 13-74. Austin: University of Texas Press.

KLEINSCHMIDT, SAMUEL P. I851. Grammatik der grönländischen Sprache. Berlin: G. Reimer.

LESSER, ALEXANDER. I985. History, evolution, and the concept of culture: Selected papers by Alexander Lesser. Edited by Sidney W. Mintz. Cambridge: Cambridge University Press.

MEINHOF, CARL. I9I2. Die Sprachen der Hamiten. Hamburg: L. Friederichsen.

. I9I5. An introduction to the study of African languages. London: J. M. Dent.

OSGOOD, CHARLES E., AND THOMAS A. SEBEOK. I954. Psycholinguistics: $A$ survey of theory and research problems. Baltimore: Waverly Press.

PARKS, DOUGLAS R. I985. Alexander Lesser I902-I982. Plains Anthropologist 30(107):65-7I.

RADFORD, ANDREW. I988. Transformational grammar: $A$ first course. Cambridge: Cambridge University Press.

SAPIR, EDWARD. I929. "Central and North American languages," in Encyclopaedia Britannica, pp. 138-4I.

SCHMIDT, WILHELM. I926. Die Sprachfamilien und Sprachenkreise der Erde. Heidelberg: Carl Winter.

STURTEVANT, E DGAR H. 1942. The Indo-Hittite laryngeals. Baltimore: Linguistic Society of America.

TUCKER, A. N., AND M. A. BRYAN. 1956. The non-Bantu languages of north-eastern Africa. (Handbook of African Languages, pt. 3.) London: Oxford University Press for the International African Institute.

WEINREICH, URIEL. I953. Languages in contact. New York: Linguistic Circle of New York.

WERNER, ALICE. I925. 2d edition. The language-families of Africa. London: Kegan Paul.

\section{The Invention of Prehistory ${ }^{1}$}

\author{
ALICE B. KEHOE \\ 3014 N. Shepard Ave., Milwaukee, Wis. S321 I, U.S.A. \\ 24 I 9 I
}

The ninth edition of the Encyclopædia Britannica, published in 25 volumes between 1875 and 1889 , has been

I. (C) I99I by The Wenner-Gren Foundation for Anthropological Research. All rights reserved 00I I-3204/91/3204-0004\$1.00. The research for this paper was pursued while I was a Visiting Fellow at the Institute for Advanced Studies in the Humanities, Edinburgh, March-August 1989. I am grateful for the support of a Marquette University Summer Faculty Fellowship and for the generosity of James Secord and James Moore in giving me papers in press as well as their published essays, Margaret Mackay in lending me Marinell Ash's manuscript on Wilson, Donald B. Smith in sending me McCardle's thesis, and Bennett McCardle in commenting on a draft of this paper. Encouragement from Barry Barnes and David Bloor, described as "the 'scholars' encyclopaedia' both because it contains essays by an exceedingly distinguished international set of scholars and because it is the first to incorporate the profound intellectual advances made in nearly all fields of nineteenth-century scholarship" (Beidelman 1974:25). Its second volume, published in I 878, met these criteria with its articles on anthropology by E. B. Tylor and on archaeology by Daniel Wilson. The latter scholar, identifying the basic premises of the science of archaeology formulated in the Igth century, had introduced the term "prehistory" into English in I85 I (Oxford English Dictionary; Chippindale I988: 303; Clermont and Smith 1990: I00) and developed the framework of a science of prehistory in his pathbreaking Prehistoric Man (1862). Whereas Robertson Smith, co-editor of the ninth Britannica, recognized these warrants to preeminence, 2oth-century scholars have ignored Wilson, omitting him from the standard histories of the discipline or dismissing him as an inconsequential dilettante (Trigger 1966, I989). Until this oversight is rectified, the foundation of Americanist archaeology will be misunderstood (Chippindale I989a: 30-32).

Wilson (1851:xi-xii) himself documented the sources of his new science of prehistory:

The zeal for Archaeological investigation which has recently manifested itself in nearly every country of Europe, has been traced, not without reason, to the impulse which proceeded from Abbotsford [Walter Scott's home]. Though such is not exactly the source which we might expect to give birth to the transition from profitless dilettantism to the intelligent spirit of scientific investigation, yet it is unquestionable that Sir Walter Scott was the first of modern writers "to teach all men this truth, which looks like a truism, and yet was as good as unknown to writers of history and others, till so taught, - that the bygone ages of the world were actually filled by living men" [here he cited Carlyle's Miscellanies, second edition, vol. v, p. 30I]. If, however, the impulse to the pursuit of Archaeology as a science be thus traceable to our own country, neither Scotland nor England can lay claim to the merit of having been the first to recognise its true character, or to develop its fruits. . . . It was not till continental Archaeologists had shewn what legitimate induction is capable of, that those of Britain were content to forsake laborious trifling, and associate themselves with renewed energy of purpose to establish the study on its true footing as an indispensable link in the circle of the sciences.

A quarter-century later, Wilson (I900 [I 878]:334-35) reiterated his conceptualization of the science of archaeology:

To those ... who are willing to follow inductive reasoning to its legitimate conclusions it must be

as well as James Secord, is especially appreciated. Secord, Diane Long Hoeveler, and Dena F. Dincauze kindly critiqued my first draft. Adam Kuper's comments have also been helpful. 